\title{
MEASURING QUALITY OF READING MATERIALS IN ENGLISH TEXTBOOK: THE USE OF LEXICAL DENSITY METHOD IN ASSESSING COMPLEXITY OF READING MATERIALS OF INDONESIA'S CURRICULUM - 13 (K13) ENGLISH TEXTBOOK
}

\author{
Dian Sari \\ State University of Padang \\ Email : jinaura@gmail.com
}

\begin{abstract}
This research seeks to study the quality of Curriculum - 13 (K13) English textbook provided by the Government of Indonesia. This will use the senior year of high school's textbook due to its emphasis on reading aspect. In order to assess the quality of K13 English textbook, in depth analysis on selected reading texts will be performed by measuring their lexical density using the Castello (2008) refers to the former way as method of calculating, which is Ure (1971) and Halliday (1985). The analysis also attempts to shed the light regarding the readability of reading texts provided in the textbook. It is important as the basis to decide whether the K13 English textbook assessed has met the aspired quality in terms of content and suitable teaching strategy to handle difficulties of the reading materials within the book. The finding revealed that higher levels of texts do not necessarily guarantee higher lexical density indexes, that is to say, the levels of texts analyzed in this study did not match he expected indexes of lexical density. This is one aspect that can be improved of the K13 English textbook.
\end{abstract}

Keywords: K 13 English Textbooks, Reading, Lexical Density, Quality.

Abstrak: Penelitian ini bertujuan untuk mengetahui kualitas dari buku teks Bahasa Inggris kurikulum 2013 (K13) yang di keluarkan oleh pemerintah Indonesia. Buku yang akan di gunakan yaitu untuk tingkat SMA dengan menekankan pada aspek bacaan (reading aspek). Pengukuran kualitas dari buku teks bahasa Inggris K13 ini dilakukan dengan analisis yang mendalam pada bacaan, yaitu dengan cara mengukur Lexical density (kepadatan lexical) dengan menggunakan teori dan metode penghitungan yang digunakan oleh Castello (2008). Metode ini merujuk teori dari Ure (1971) dan Halliday (1985). Analisis teks yang dilakukan bertujuan untuk melihat keterbacaan teks yang ada pada buku. Hal ini penting dilakukan untuk mengetahui apakah buku teks Bahasa Inggris K13 berkualitas secara isi, sehingga guru dapat menentukan strategi mengajar yang sesuai pasa siswa. Dalam penelitian ini ditemukan bahwa tingkat kelas yang lebih tinggi tidak menjamin tingginya indeks Lexical density. Hasil analisis dari penelitian ini bahwa level teks tidak cocok dengan indeks lexical density yang di harapkan. Karena itu diharapkan buku Bahasa Inggris K13 dapat lebih memperhatikan indeks lexical density bacaan.

Kata Kunci: Buku Bahasa Inggris K13, Bacaan, Lexical Density, Kualitas. 


\section{INTRODUCTION}

The K13 English textbook (the English student' book for 2013 curriculum for secondary schools in Indonesia) is a new English textbook introduced by the Ministry of Education and Culture of Indonesia that is adjusted in accordance with the new designed curriculum introduced in 2013 replacing the 2006 curriculum (Kurikulum Tingkat Satuan Pendidikan- KTSP/School Based Curriculum).

In consideration with the widespread use of the K13 English textbooks as new textbook that has essential role as the main access of learners in facilitating language learning, therefore, this textbook will be the main object of analysis. From the policy perspective, the urgency to assess this textbook is also coming from the resistance of many teachers towards the quality of the book. As one of the facilitators of K13 in 2014 period, the author encounter many critiques that saying this book has a lower quality in comparison of similar textbook published by the private publishing or previous KTSP English textbook. This has increased the currency of the issues, especially to assess the quality of the book and objectively compare the textbook.

\section{Literature Review}

Lexical density is a term that is used in text analysis or content analysis. The degree of lexical density on the text will influence the ability of student to understand the English text. The lexical density is a measure of ratio of the text's content words to its function words. Johansson (2008:65) had definition that "lexical density is the term which is most often used for describing the proportion of content words to the total number of words." Halliday (1985:63) further explained that the lexical density is number of lexical items as the proportion of the number of running words. He refers to use lexical items than lexical word because they may consist of more than one word, for example stand up, take over, call off, and other phrasal verbs all function as single lexical items.

With regard to writing, lexical density is simply a way to measure how informative a text is (Didau, 2013). As a general rule texts with lots of lexical words tend to be specialized academic texts only comprehensible to well-educated folk in specific fields. A value which ranges is from 0 to 100. In general, the greater the lexical density of a text, the more content heavy it is and more 'unpacking' it takes to understand, texts with low lexical density are easier to understand. Or low numbers of lexical words result in easy-to-understand writing. And if the number of lexical words is too low, writing becomes meaningless and vague. Balanced lexical density is approximately 50 percent. This means that half of each sentence is made up of lexical words and half of functional words. A lowdensity text will have less than 50:50 ratios and a high-density text will have more than 50:50. Academic texts and government, jargon-filled documents tend to produce the highest densities.

There have been several past studies had used lexical density as a tool to assess different variables in examining various type of text and different outcomes have 
been achieved. For example, Cheryl in 1995 conducted study that used lexical density to measure quality of writing by investigating its relations with proportion of content words. By so doing, Cheryl had attempted to prove the significance of lexical density on written language. In 2008, Johansson attempted to measure age factors in ability of individual to comprehend complexities in speaking and listening. He used lexical density as the method in measuring the language complexities. In 2013, To Vin, and Thomas, attempted to assess complexities of reading text of English textbook by using lexical density. The aforementioned examples were interesting example on the use of lexical density to measure language complexities within different contexts. These have provided evident that lexical density is a useful tool in measuring language complexities.

\section{METHODOLOGY}

This research aims to evaluate reading texts and describe the result of the evaluation by investigate the lexical density of reading text from K13 English textbooks. This study, therefore, is a qualitative research using a descriptive - evaluative content analysis as its tools.

The objectives of this study are:

1. To find out the lexical density that presented in reading passages of English textbooks.

2. To compare between levels (class $\mathrm{X}$, class XI, and class XII) in order to find changes on how the lexical density index increase in accordance with the set difficulty level of texts between levels.

This study employs the methods purposed by Castello (2008) refers to the former way as method of calculating, which is Ure (1971) and Halliday (1985), the lexical density represented in the following formula (p. 59):

Lexical Density (\%) $\frac{\text { Number of content words }}{\text { Total Number of Words (Tokens) }} \times 100 \%$

The data of the present study are taken from English textbook for grade $\mathrm{X}$ senior high school written by Utami Widiati, Zuliati Rahmah, and Furaida, English textbook for grade XI senior high school written by Mahrukh Bashir and English textbook for grade XII senior high school written by Utami Widiati, Zuliati Rahmah, dan Furaida. All of the books publish by Departement of Education of Indonesia in 2014 and 2015. In the recent years, those books have become the teaching materials in Indonesia suggested by the Ministry of Education. The textbooks have been printed and disseminated to the schools around Indonesia. To achieve the availability of the books, the Ministry of Education and Culture has also entitled textbooks' copyright and provided the electronics version of the K13 books for free.

\section{FINDINGS AND DISCUSSION}

Findings 
Table 1: The Data of Lexical Density in Class $X$

\begin{tabular}{|l|l|l|l|l|l|}
\hline No. & Texts & $\begin{array}{l}\text { Total } \\
\text { words }\end{array}$ & $\begin{array}{l}\text { Content } \\
\text { Words }\end{array}$ & $\begin{array}{l}\text { Functional } \\
\text { words }\end{array}$ & $\begin{array}{l}\text { Lexical } \\
\text { Density }\end{array}$ \\
\hline 1. & Congratulation & 359 & 182 & 177 & $50.70 \%$ \\
\hline 2. & My Best Friend & 221 & 109 & 112 & $49.32 \%$ \\
\hline 3. & Tanjung Putting National Park & 265 & 137 & 128 & $51.70 \%$ \\
\hline 4. & Batu City & 291 & 152 & 139 & $52.23 \%$ \\
\hline 5. & Visiting Niagara Falls & 477 & 258 & 219 & $54.09 \%$ \\
\hline 6. & The Secrets of Stonehenge & 378 & 191 & 187 & $50.53 \%$ \\
\hline 7. & Meeting My Idol & 361 & 177 & 184 & $49.03 \%$ \\
\hline 8. & Diary & 432 & 190 & 242 & $43.98 \%$ \\
\hline 9. & BJ Habibie & 499 & 311 & 188 & $62.32 \%$ \\
\hline 10. & Cut Nyak Dhien & 592 & 322 & 270 & $53.39 \%$ \\
\hline 11. & Issumboshi & 670 & 338 & 332 & $57.91 \%$ \\
\hline 12. & The Legend of Malin Kundang & 408 & 221 & 187 & $51.72 \%$ \\
\hline
\end{tabular}

Table 1 gives insight of the lexical density measured over the 12 reading texts contained in the K13 English textbook of class X. From the table above, it can be seen that the lexical density index is considerably high, with the average lexical density for all reading texts in K13 English textbook is $51.55 \%$. Text titled BJ Habibie has the highest lexical density with percentage of $62.32 \%$. And the lowest one is title Diary with percentage of $43.98 \%$. The text titled Issumboshi has the highest total number of words is 670 with the lexical density come number second with $57.91 \%$.

Table 2: The Data of Lexical Density in Class XI

\begin{tabular}{|l|l|c|c|l|l|}
\hline No. & Texts & $\begin{array}{l}\text { Total } \\
\text { words }\end{array}$ & $\begin{array}{l}\text { Content } \\
\text { Words }\end{array}$ & $\begin{array}{l}\text { Functional } \\
\text { words }\end{array}$ & $\begin{array}{l}\text { Lexical } \\
\text { Density }\end{array}$ \\
\hline 1. & The Enchanted Fish & 1021 & 455 & 566 & $44.56 \%$ \\
\hline 2. & Bullying & 775 & 404 & 371 & $52.13 \%$ \\
\hline 3. & President Sukarno' Speech & 499 & 212 & 287 & $42.48 \%$ \\
\hline 4. & Letter to God & 1142 & 540 & 602 & $47.29 \%$ \\
\hline 5. & Story of Technical Writing & 855 & 513 & 342 & $60.71 \%$ \\
\hline 6. & Earthquakes & 524 & 306 & 220 & $58.40 \%$ \\
\hline 7. & The Last Leaf & 1026 & 518 & 508 & $50.49 \%$ \\
\hline
\end{tabular}




\begin{tabular}{|l|l|c|c|c|c|}
\hline 8. & $\begin{array}{l}\text { Life and Time of Ki Hajar } \\
\text { Dewantara }\end{array}$ & 658 & 315 & 343 & $47.87 \%$ \\
\hline 9. & Global Warming & 647 & 336 & 311 & $51.93 \%$ \\
\hline
\end{tabular}

Table 2 gives insight of the lexical density measured over the 9 reading texts contained in the K13 English textbook of class XI. From the table above it can be concluded that the average lexical density is considerably high or lexically dense with percentage of $50.57 \%$. Text titled Story of
Technical Writing has the highest lexical density with percentage of $60 \%$. And the lowest one is President Sukarno' Speech with percentage of $42.48 \%$. Text titled Letter to God has the highest total number of words with 1142, but considerably low in terms of its lexical density.

Table 3: The Data of Lexical Density in Class XII

\begin{tabular}{|l|l|l|l|l|l|}
\hline No. & Texts & $\begin{array}{l}\text { Total } \\
\text { Words }\end{array}$ & $\begin{array}{l}\text { Content } \\
\text { Words }\end{array}$ & $\begin{array}{l}\text { Functional } \\
\text { Words }\end{array}$ & $\begin{array}{l}\text { Lexical } \\
\text { Density }\end{array}$ \\
\hline 1. & What is Reptile? & 65 & 35 & 30 & $52.31 \%$ \\
\hline 2. & Dinosaurs & 129 & 61 & 68 & $47.29 \%$ \\
\hline 3. & Zebra & 567 & 307 & 260 & $54.14 \%$ \\
\hline 4. & Tornado & 213 & 101 & 112 & $47.42 \%$ \\
\hline 5. & Teenage Bullying & 362 & 202 & 160 & $55.80 \%$ \\
\hline 6. & Best Friend Forever & 188 & 98 & 90 & $52.13 \%$ \\
\hline 7. & Pottery & 514 & 311 & 203 & $60.51 \%$ \\
\hline 8. & Baduy People & 451 & 244 & 207 & $54.10 \%$ \\
\hline 9. & Humber Bridge & 102 & 50 & 52 & $49.02 \%$ \\
\hline 10. & The Jakarta Metropolitan & 95 & 55 & 40 & $57.89 \%$ \\
\hline 11. & Tenants Advised ... & 211 & 107 & 104 & $50.71 \%$ \\
\hline 12 & Parents upset ... & 518 & 252 & 266 & $48.65 \%$ \\
\hline 13. & $\begin{array}{l}\text { Indonesia Open Regional } \\
\text { Recycling }\end{array}$ & 225 & 114 & 111 & $50.89 \%$ \\
\hline 14. & $\begin{array}{l}\text { How to Make Chocolate dipped } \\
\text { Strawberries }\end{array}$ & 108 & 63 & 45 & $58.33 \%$ \\
\hline 15. & Trip to Botanical Garden & 113 & 46 & 67 & $40.70 \%$ \\
\hline 16. & Head Lice & 138 & 71 & 67 & $51.44 \%$ \\
\hline 17. & How to Breed Leopard Geckos & 590 & 288 & 302 & $48.81 \%$ \\
\hline
\end{tabular}

Table 3 gives insight of the lexical density measured over the 17 reading texts contained in the K13 English textbook of class XII. From the table above it can be concluded that the average lexical density is considerably high or lexically dense with 
percentage of $51.77 \%$. Text titled Pottery has the highest lexical density with percentage of $60.51 \%$. And the lowest one is Trip to Botanical Garden with percentage of $40.70 \%$. Text titled Letter to God has the highest total number of words with 1142, but considerably low in terms of its lexical density. Text titled 'How to Breed Leopard Geckos' has the highest total number of words with total words of 590, with low lexical density of $48.81 \%$.

Table 4: The Average of Total Number of Words and Lexical Density.

\begin{tabular}{|l|l|l|}
\hline Class & Total Number of Words & Lexical Density \\
\hline X & 412,75 & $51,91 \%$ \\
\hline XI & 794,11 & $50,57 \%$ \\
\hline XII & 269,94 & $51,77 \%$ \\
\hline
\end{tabular}

From table 4 above, the highest average of total number of words is in class XI, 798.11. And the lowest is in class XII, 269.94. The highest average of lexical density is in class $\mathrm{X}, 51.91 \%$. And the lowest is in class XI, $50.57 \%$.

Discussion

The first question in this study is how the lexical density is presented in the reading passages of K 13 English textbooks. With a careful analysis of lexical density in the reading passages in each class, the results revealed that almost all of the class has considerably high lexical density index (above 50 percent).

Although the lexical density is not the only measure to determine readability and difficulty of the text, the sporadic and inconsistent spread of lexical density shown the problematic nature of text provided in the K13 English textbooks for Senior High School.

Figure 1: The Three Highest Lexical Densities from Each Class

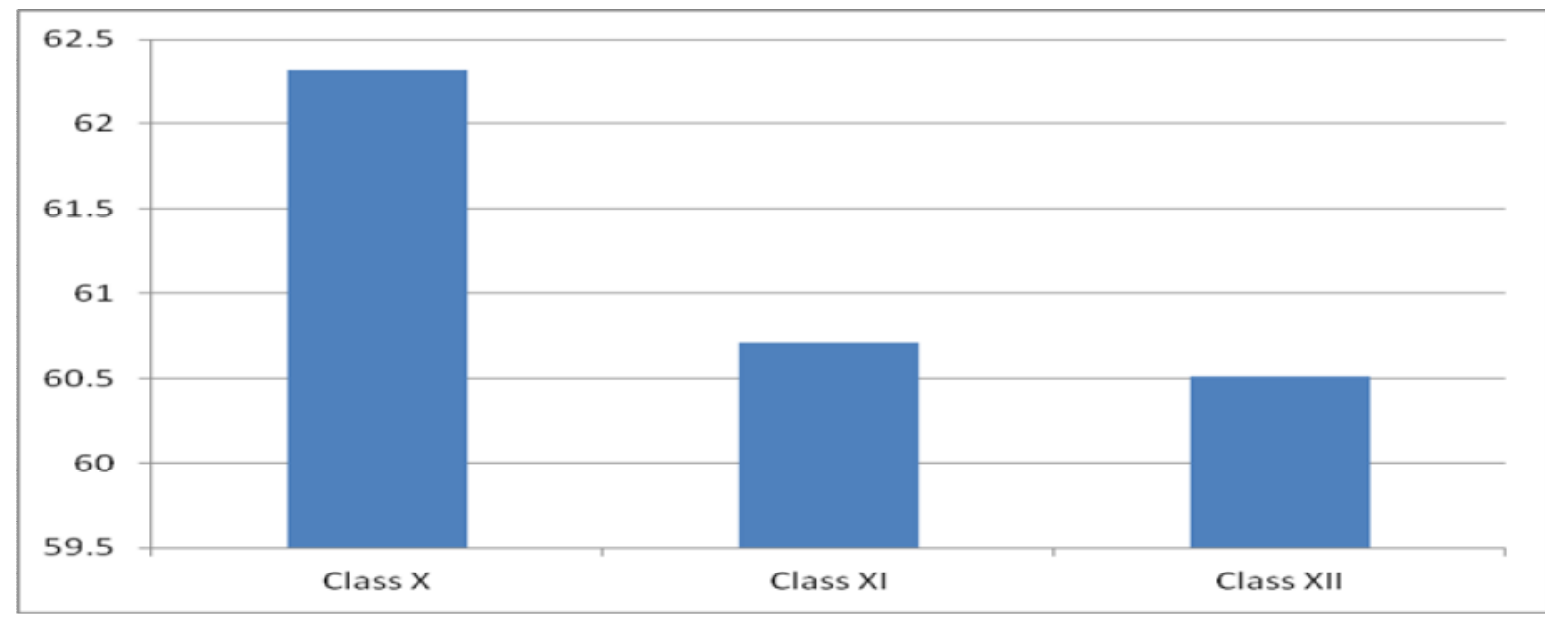

The figure above compares the Habibie from the class $\mathrm{X}$ has the highest percentage of the three highest lexical densities from each level. From the figure above, it can be seen that the text titled BJ lexical density with percentage of $62.32 \%$ in comparison of all text in class XI and XII. The second highest is from the class XI 
titled Story of Technical Writing with $60.71 \%$ percentage of lexical density. It is then followed by the text from the class XII 60.51 percent. This finding is interesting to note as the most difficult text or the text that has the highest lexical density is found in the class X instead of class XII.

The highest level of lexical density caused the difficulty for student in understanding reading passages. With regard to writing, lexical density is simply a way to measure how informative a text is (Didau, 2013). As a general rule texts with lots of lexical words tend to be specialized academic texts only comprehensible to well-educated folk in specific fields. A value which is ranges from 0 to 100 . In general, the greater the lexical density of a text, the more content heavy it is and more 'unpacking' it takes to understand, texts with low lexical density are easier to understand. Or low numbers of lexical words result in easy-to-understand writing. And if the number of lexical words is too low, writing becomes meaningless and vague.

\section{Figure 2: The Three Lowest Lexical Densities from Each Class.}

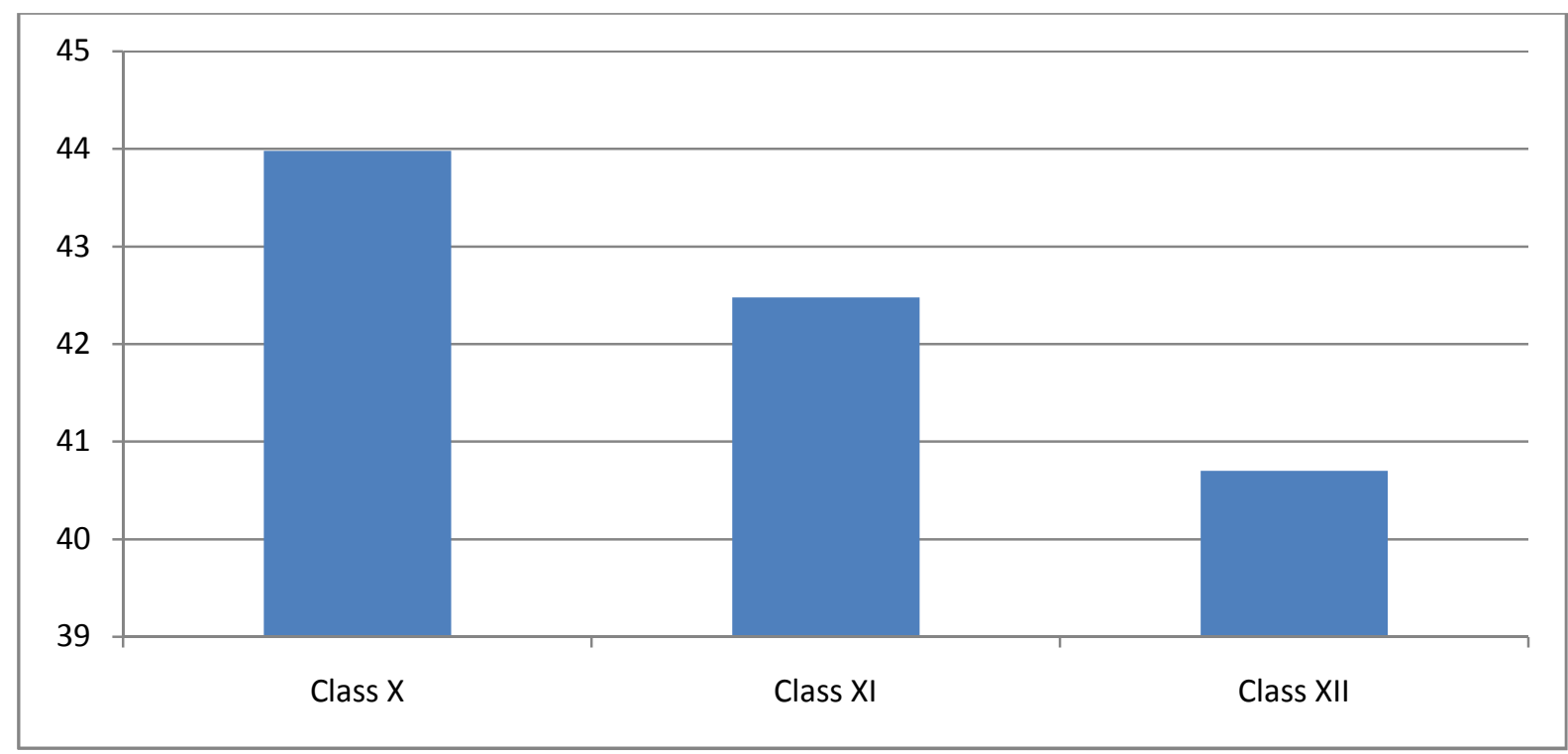

Figure 2 is shown the three lowest lexical density indexes from each class. From the table above can be shown that the text from class XII titled Trip to Botanical Garden has the lowest lexical density with 40.70 percent. It followed by text titled President Sukarno's Speech from the class XI with 42.48 percent, and then text titled Diary from class X with 43.98 percent. This finding is also interesting to note as the least difficult text or the text that has the lowest lexical density is found in the class XII instead of class $X$.

The second question of this study is how to do lexical density in reading passages between three levels differ or resemble. As can be seen in the Figure 3 below, the average lexical density of each class shown fluctuated pattern of changes, from 51.55 percent for class $\mathrm{X}$, down to 50.57 percent for class XI, and rose to 51.77 percent for class XII. Although it may be 
assumed that lexical density changes in accordance with the set difficulty level of text, the result of this study shown that the
K13 English textbooks for the Senior High do not follow such notion.

Figure 3: Average Lexical Density in All Class.

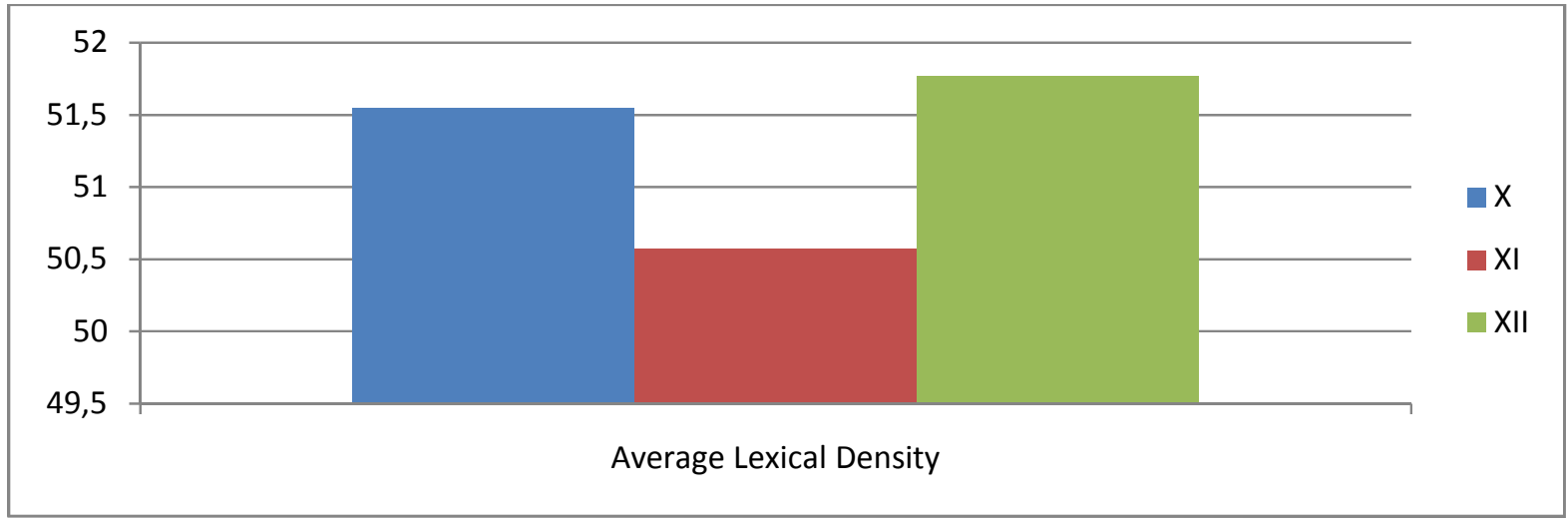

Further, when we measured the the percentage of the lowest lexical density percentage of the highest lexical density and as can be seen below.

Figure 4: The Percentage of The Highest Lexical Density and The Percentage of The Lowest Lexical Density.

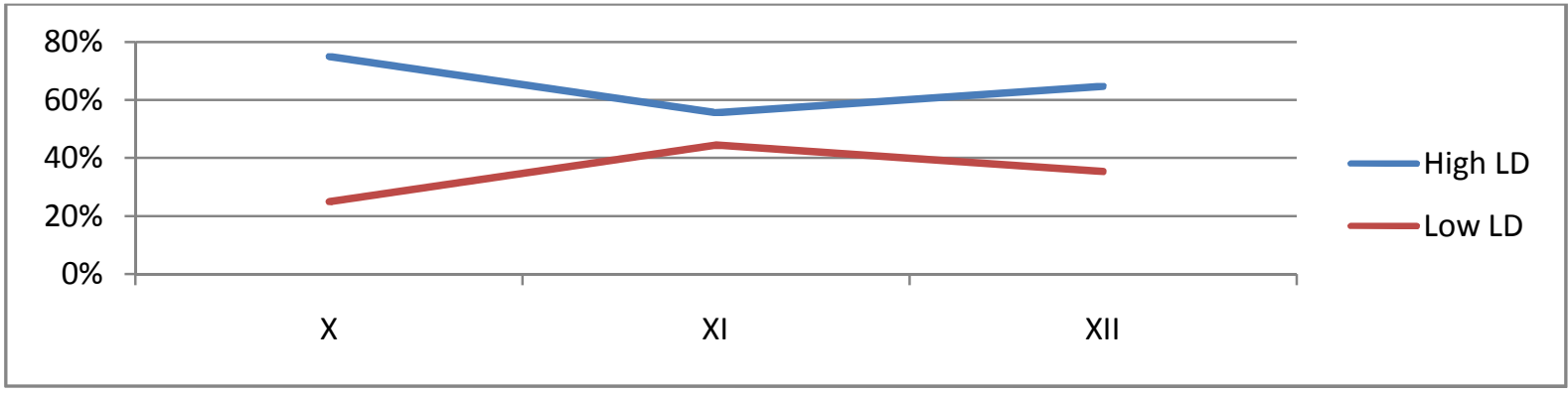

It can be seen that the percentage of the highest lexical density is concentrated in the class X. 75 percent of the text in the class $\mathrm{X}$ has high lexical density, followed by class XII with 64.70 percent and class XI with 55.55 percent. Similarly, the class XI has the highest percentage for lowest lexical density with 44.44 percent, followed by class XII with 35.30 percent and class X with 25 percent.

\section{CONCLUSION}

This study examines and assesses the quality of selected reading materials provided in the K13 English textbooks for Senior High School provided by the Minister of Education of Indonesia. Hence, this research attempts to answer two major questions: To find out the lexical density that presented in reading passages of English textbooks; and to compare between levels (class X, class XI, and class XII) in order to find changes on how the lexical density index increase in accordance with 
the set difficulty level of texts between levels. Qualitative study was employed using a descriptive - evaluative content analysis as its tools. The research used lexical density as its main guiding theory with the classification of grammatical and lexical items formulated by Castello (2008). The lexical density analysis was seen as important to shed the light on whether the reading material is accessible for students.

First, the finding above revealed that almost all of the class has considerably high lexical density index (above 50 percent). This means that the K 13 English textbooks are lexically dense. This can be advantageous for teaching student in medium to advance level (majority of student in urban city), but those in rural area who have poor to medium English will likely to be struggling. Hence, it reduces the wider benefits of the book. Moreover, comparing the percentage of the three highest lexical densities from each level, it was found that class $\mathrm{X}$ has the highest lexical density. This finding is interesting to note as the most difficult text or the text that has the highest lexical density is found in the class $\mathrm{X}$ instead of class XII. From comparison above, it was also found that the text from class XII has the lowest lexical density instead of class X. As explained above, despite lexical density is not the only measure to determine difficulty of the text, the sporadic and inconsistent spread of lexical density shown the problematic nature of text provided in the K13 English textbooks for Senior High School.
Second, after comparing between levels (class X, class XI, and class XII), it was found that the average lexical density of each class shown fluctuated pattern of changes, from 51.55 percent for class $\mathrm{X}$, down to 50.57 percent for class XI, and rose to 51.77 percent for class XII. This means that lexical density of the K13 English textbook does not changes in accordance to the set difficulty level of text. It was also found that the percentage of the highest lexical density is concentrated in the class $X$ whereby 75 percent of the text in the class $x$ has high lexical density, followed by class XII and class XI. Similarly, the class XI has the highest percentage for lowest lexical density with 44.44 percent, followed by class XII and class X.

Overall it can be concluded that higher levels of texts do not necessarily guarantee higher lexical density indexes, that is to say, the levels of texts analyzed in this study did not match he expected indexes of lexical density as illustrated in the figure above. This is one aspect that can be improved of the K13 English textbook.

\section{REFERENCES}

Bashir, Mahrukh 2014 Buku Siswa Bahasa Inggris Kelas XI. Pusat Kurikulum dan Perbukuan, Balitbang, Kemdikbud Jakarta.

Castello, E. 2008.Text Complexity and Reading Comprehension Tests Reading Notes.http://adrien.barbaresi.e u/blog/e-castello-text-complexity-andreading-comprehension-tests-readingnotes.html

Cheryl, A.E. 1995. The Relationship of Lexical Proficiency to The Quality of 
ESL Compositions. Journal of Second Language Writing, 4(2), 139-155.

Didau, David (2013), Black space: improving writing by increasing lexical density, from The Learning Spy: Brain Food for the Thinking Teacher Halliday, M.A.K. 1985. Spoken and Written Language. Victoria: Deakin University Press.

Johansson, V. (2008), Lexical diversity and lexical density in speech and writing: a developmental perspective, Working Papers 53, 61-79.

To, Vinh Fan Si. and Thomas, Damon. 2013. Lexical Density and Readability: A Case Study of English Textbooks.
Internet Journal of Language, Culture and Society, 37, 61-71.

Ure, J. (1971), Lexical density and register differentiation. In G. Perren and J.L.M. Trim (eds), Applications of Linguistics, London: Cambridge University Press. 443-452.

Widiati, et.al.; 2015, Buku Siswa Bahasa Inggris Kelas XII. Pusat Kurikulum dan Perbukuan, Balitbang, Kemdikbud Jakarta.

Widiati, et.al.; 2014, Buku Siswa Bahasa Inggris Kelas X. Pusat Kurikulum dan Perbukuan, Balitbang, Kemdikbud Jakarta. 